\title{
動摇する角型タンク内の動的水圧一II
}

\author{
木 村 隆 一*.今 枝 彬 郎*
}

\section{Dynamic Pressure in Oscillating Rectangular Tank-II}

\author{
Ryuichi KIMURA and Yoshiro IMAEDA
}

\begin{abstract}
Dynamic pressure of water on the wall was measured using a rigid rectangular model tank (Dimension: $100 \mathrm{~cm} \times 100 \mathrm{~cm} \times 30 \mathrm{~cm}$ ) which was forced to roll with constant amplitude of 6 degrees.

A series of experiments were made for a numerous combinations of three factors: water levels (WL), the oscillation periods(T) and the distance(D) between the center of oscillation and that of the tank.

The effect of the said distance $D$ appears to prevail over that of the water levels(WL) and $\operatorname{period}(T)$.

That is, the more $\mathrm{D}$ is increased,

i ) the larger the dynamic pressure grows over the wider area of the wall.

ii) the larger the dynamic pressure begins to the exert at larger period( $T$ ) compared to the resonance period.
\end{abstract}

\section{1.はじめに}

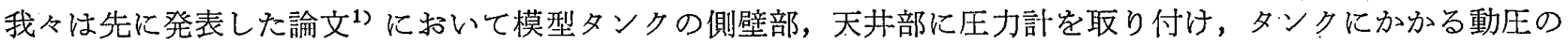
分布等を実測し報告した。

前報では水位を 90\%，60\%，30\% と変え動摇周期も種々に変えて実測した。その結果いずれの場合でも静水 面付近の側壁の位置で大きな動圧を発生し，また衝撃圧が発生する場合では水位が変わることにより衝撃圧発生 の機構が異なることがわかった。

しかし前報の実験では動摇試験装置の構造上，タンクの底が動摇台の動摇中心より $38 \mathrm{~cm}$ 上にある場合しか実 験出来なかった。

今回，我々はこの動摇試験装置に鉄骨の枠組を設けタンクをその枠に沿って上下出来るようにした。したがっ て動摇中心とタンク中心との距離を種々に変化させることが可能となった。

本論文では主にタンクと動摇中心との距離に着目して水位, 動摇周期を種々に変えた時のタンク内に発生する 動圧について考察した。

\section{2. 実験}

2.1 動摇装置

実験は前報で使用した動摇試験装置を用いた。図 1 に示すように動摇装置の載貨台の左端に鉄骨の枠組を設 け，枠組内にタンクを置くようにした。タンクは枠組内で上下に移動出来るようになっているためタンク中心と 動摇中心とは $80 \mathrm{~cm}$ 程自由に変えられるようになった。またタンクを最下端をで下降させた時はタンク中心と動

* 正会員 神戸商船大学（神戸市東灘区深江南町 5 丁目 1-1) 


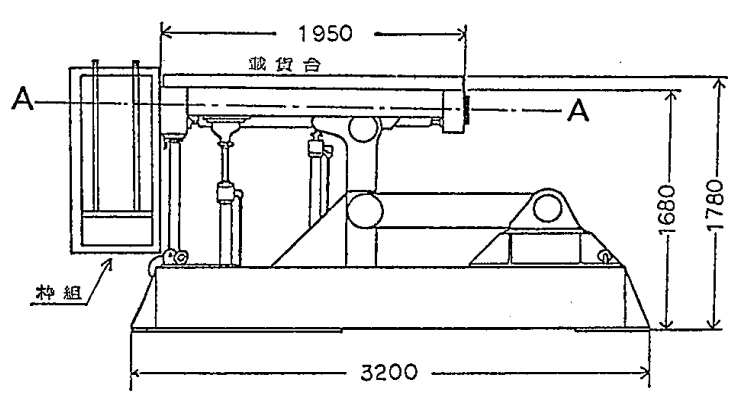

図 1 動摇装置

摇中心が一致するようになっている。

この動摇装置は上下動, 縦摇れ, 横摇れ等の動きをさせ ることが出来るが今回の実験では横摇れのみを使用した。 この動摇装置で横摇れとは図中の $\mathrm{A}$-A軸の回りに回転す ることを言う。

\section{2 模型タンク}

実験には図 2 に示すような模型タンクを製作した。前回 使用したタンクは鉄板製で正面に透明塩ビ板を用いたが， その正面においても透明塩ビ板の取付部があったためタン クの正面周辺部では液体の動き䓂観察出来なかった。図 2

に示す模型タンクはほとえど透明塩ビ板を使用している。周辺部に補強材のし型アングルを用いているがタンク 内壁はタンクの雨端部よりとれぞれ $10 \mathrm{~cm}$ 内側に設けたため液体の運動する部分は十分観察出来るようになって いる。

圧力計はこの内壁に取り付けるようにした。そして圧力 計はこの側面上に称いて垂直方向であればどの位置にで も，また複数個でも固定出来るようになっている。

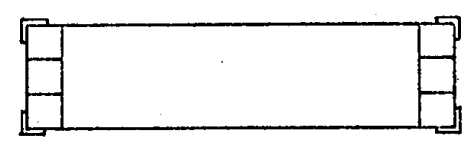

\section{3. 実 験 結 果}

3.1 水位变化

図 1 に示す動摇中心軸 $\mathrm{A}$ - $\mathrm{A}$ に対し; 左端の模型タンク を上下に移動して，タンクの位置を 3 段階に变化させた。 それぞれのタンクを固定した位置で水位を变えた時の压力 特性を図 3 に示した。図中の $z_{1}, z_{2}, z_{3}$ はタンクがどの位 置にあったが表わしたものである。（ $z_{1}$ ：タンク中心と 動摇中心が一致した時, $z_{2}$ ：動摇中心から上方 $35 \mathrm{~cm}$ にタ ソク中心がある時， $z_{3}$ : 動摇中心から上方 $80 \mathrm{~cm}$ にタンク 中心がある時) 横軸はタンクの高さ $1000 \mathrm{~mm}$ を $100 \%$ と
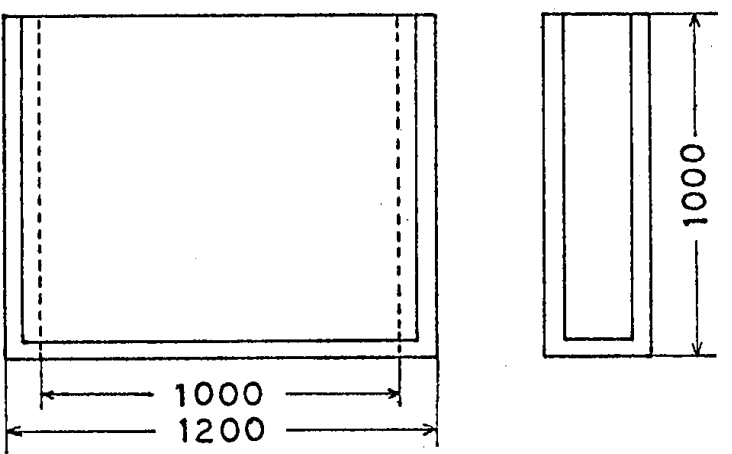

図 2 模型タンク してタンクに满たした水の高さを％表示している。縦軸

は動圧 $\Delta P$ をタンク幅 $2 a$ で無次元化した值を示している。動摇周期は $T / T_{n}=1.0$ と 1.1 ( $T:$ 強制動摇周 期， $T_{n}$ : タンク内の流体の自然固有周期）の場合を図 3 の上図と下図に示した。压力の測定場所は側壁上で液 面の位置とした。

タンクが $z_{1}$ の位置にある時は図 3 の上図，下図共に（T/Tn=1.0,1.1 の場合）水位 $10 \%$ から水位 $90 \%$ 字で特に高い压力を出す水位はなくほぼ一定の低い值となっている。その最高值でも 0.3 位の值である。しか し，タンクを上昇させて $z_{2}$ の位置になると水位によって圧力の值が大きく变わるようになる。上図 $T / T_{n}=1.0$ の場合, 水位 $20 \%$ の所で $\Delta P / 2 a$ が 2.2 程度の非常に大きな值を示している。又水位 $90 \%$ でも 0.6 程の圧 力となっている。

図 3 の下図において， $z_{2}$ で $T / T_{n}=1.1$ では水位 $20 \%, 50 \%, 90 \%$ で高い压力出している。水位 $20 \%$ の 時は $T / T_{n}=1.0$ と比べると急激に減少して 0.6 位の值になっている。さらにタンクを上昇させた $z_{3}$ の位置 では $T / T_{n}=1.0$ の時, 水位 $60 \%$ から $90 \%$ まで $0.6 \sim 1.0$ 位の高い压力を発生している。水位 $20 \%$ で 0.6 位の值を示している。 $T / T_{n}=1.1$ になると水位 $20 \%$ で特に高い 3.0 に近い值を示す。水位 $30 \%$ から水位 $90 \%$ までは大体 $0.6 \sim 0.8$ 程度の值となっている。

これらのことよりタンクが $z_{1}$ の位置ではどの水位においてもあまり大きな玨力はとらないが $z_{2}$ になる特 に高い圧力を示す水位 $20 \%$ および $50 \%$ ，90\% という高い压力を示す水位があることがわかる。そして なるとどの水位でも全体的に高い压力を示すようになる。

3.2 タンク位置の変化 

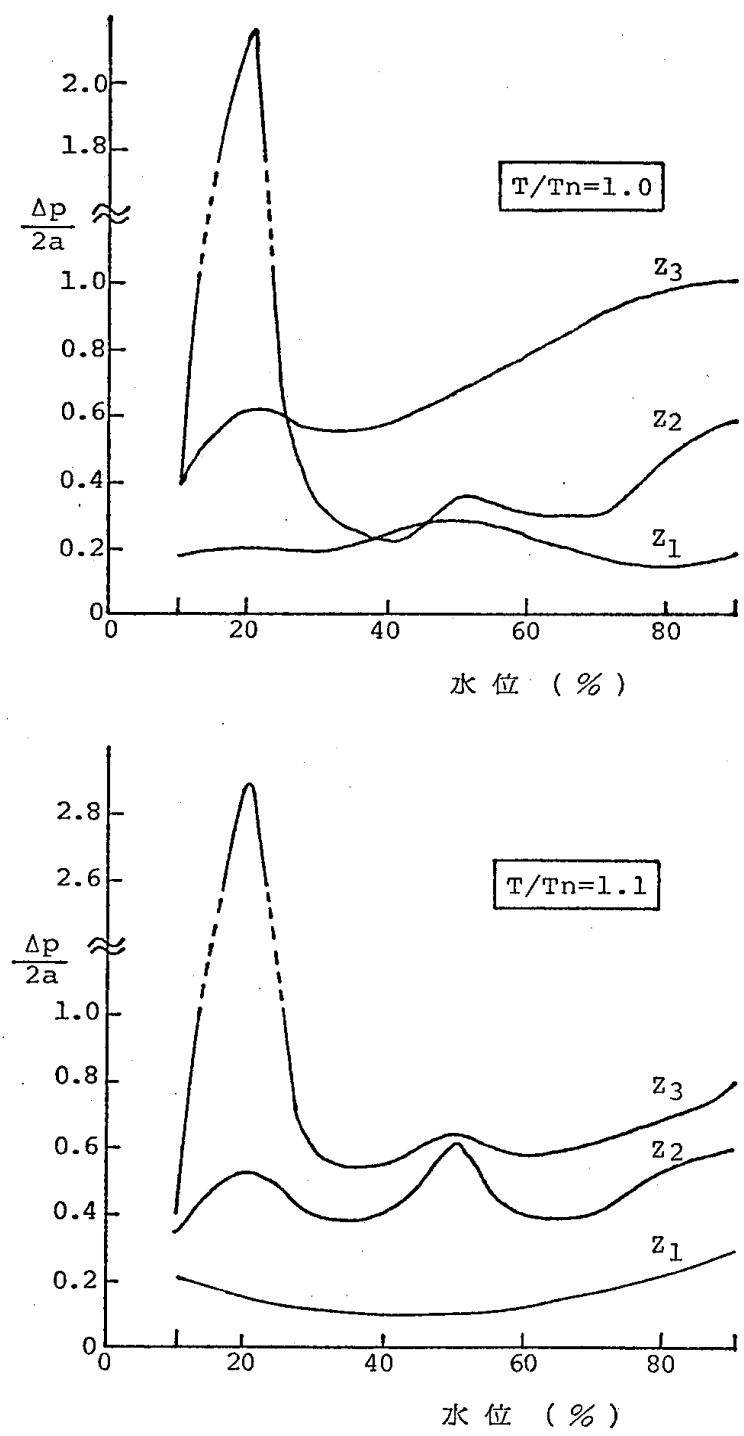

図 3 水位変化

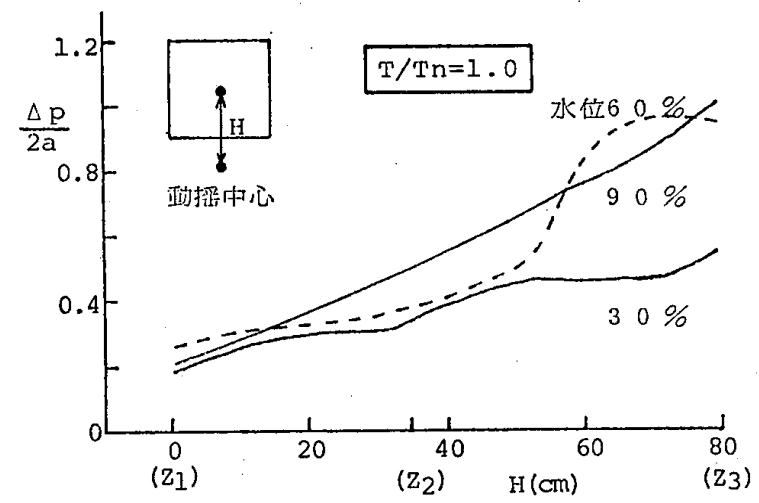

図 4 タンク位置の変化（水位 $90 \% ， 60 \%, 30 \%$ )

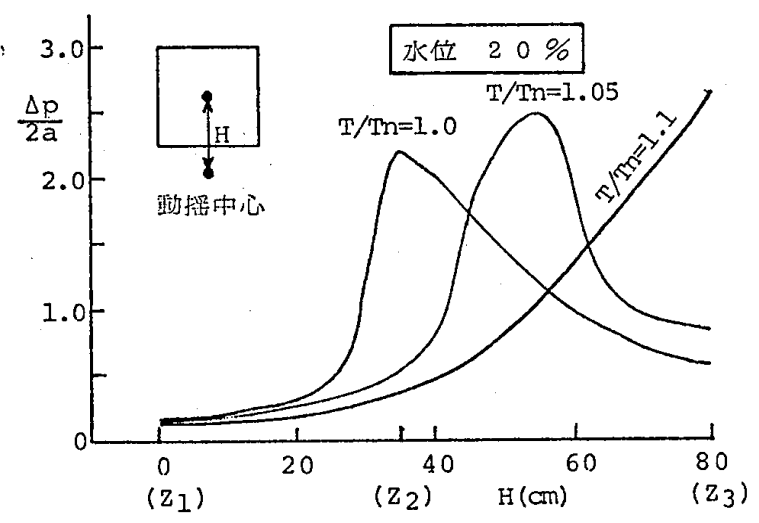

図 5 タンク位置の変化（水位 20\%）

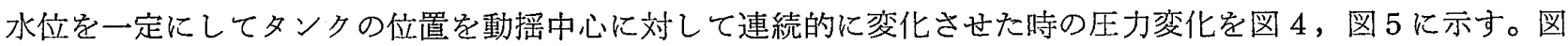
4 には水位を $30 \% ， 60 \% ， 90 \%$ とそれぞれ一定水位のもとで行なった実験結果を示す。水位 20\% の場合は図 3 でもわかるように特に高い圧力を示すので別に図 5 として示している。

図 4, 図 5 の横軸は, 動䁘中心からタンク中心をでの距離である。従って横軸の0は動摆中心とタンク中心が 一致した時であり，右端の 80 はタンクが動摆中心より上方に最も離れた時である。な撗軸上の $z_{1}, z_{2}, z_{3}$ は 図 3 のようにタンクの位置を固定して実験したときのタンクの位置を示している。縦軸は動压 $\Delta P$ を無次元化し た值である。圧力計はいずれも側壁の静水面の位置に取り付けて測定した。

図 4 において水位 $30 \%$ の場合は $H=0$ の時王力は約 0.2 で $H$ 唯増加すると共に圧力も徐々に増加し，H $=30$ から圧力上昇が少し大きくなる。これは水位 $30 \%, H=30 \mathrm{~cm}$ の時, 丁度水面と動摇中心が一致し, $H=$ $40 \mathrm{~cm}$ では水面の方が動摇中心より上にくる。したがって，水の運動が $H=30$ 它境に変わるためであると思わ れる。

水位 $60 \%$ の場合も $H=0$ では压力 0.2 程度である。 $H$ の增加と共に $H=50$ 位までは圧力が徐々に增加す る。 $H=50$ から $H=60$ の間で急激な圧力の增加がある。これは $H$ の增加と共に水の動きが激しくなり，前報 で報告した様にタンクの側壁面に沿って上昇した水が天井に沿って流れ次に天井から反対の壁に向かって激突す る。つまり $H=50$ から $H=60$ の間でこの激突する現像が起きる。したがって $H=60$ では圧力が 0.8 程度の 大きな值になる。 
水位 $90 \%$ では $H=0$ から $H=80$ \&で大体一定の割合で圧力が増加している。水位 $90 \%$ の時水面付近の大 きな圧力は水面が天井に衛突することによって発生する衝撃压によるものであることは前報でも述べた。したが ってH の值が大きくなり水の動きが激しくなればそれだけ天井に当たる衝撃も強くなる。つまり水位 $90 \%$ で は水位 $30 \%$ や水位 $60 \%$ のように H の值によって水の動きが大きくなり壁に激突するような現象は生じない ため大体一定の割合で圧力が增加する。

図 5 の水位 $20 \%$ の場合，動眇周期は $T / T_{n}=1.0 ， T / T_{n}=1.05 ， T / T_{n}=1.1$ の三種類を示した。この図よ り水位 $20 \%$ では $H$ の值によって压力は非常に大きな変化をすることがわかる。 $H=0$ から $H=20$ までは $T / T_{n}=1.0,1.05,1.1$ ともに压力 0.2 程度の小さな值である。これは水位 $30 \%$ のところでも述べたが， $H$ $=20$ の時は水面が動摆中心よりも下にあり水が動きにくいためと考えられる。

$T / T_{n}=1.0$ で動摇させると $H=30$ 位から圧力は急激に増大し $H=35$ で最大值 2.2 程度の非常に大きな圧 力を発生する。しかし $H$ の值が 35 以上になると次第に圧力は减少して，H=80 $\left(z_{3}\right)$ の位置ではほぼ 0.6 前 後の值になる。又 $T / T_{n}=1.05$ では $H=55$ 位で最大压力 2.5 程の值をとっている。そして $T / T_{n}=1.1$ では $H$ が最大の值をとる $H=80$ (タンクを最上端まで上昇させを時) で最大圧力 2.5 位の值となっている。このよ
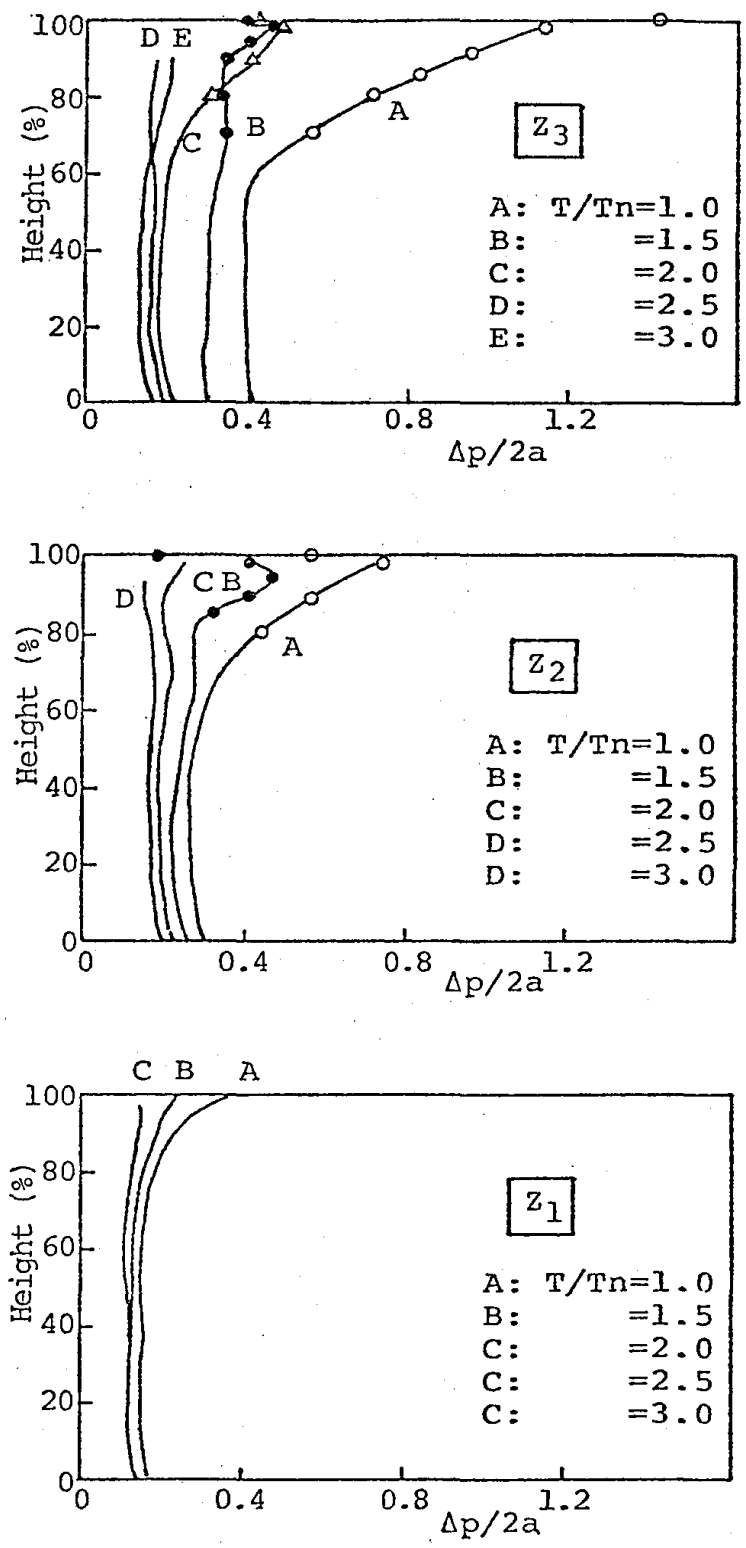

図 6 水位 $90 \%$ 時の壁に括ける压力分布 うに動擉周期 $\left(T / T_{n}\right)$ が和そくなると共に最大圧力を発 生する所が $H$ の值の大きい方へと变わっていくことがわ かる。つまりタンクが動摇中心から離れるほど $T / T_{n}=$ 1.0 よりおそい周期で共振のようになり最大圧力を発生す る。したがって $T / T_{n}=1.0$ の時は $H=35\left(z_{2}\right)$ の位置 で最大圧力となっているにもかかわらず，動摇周期の少し 違った $T / T_{n}=1.1$ では正力 0.3 程度の非常に小さな值 となっている。しかし $H=80$ に掠いては逆に $T / T_{n}=$ 1.1 の方が大きい值になっている。

つまり動摇周期が $T / T_{n}=1.0$ の付近では少しの動摇周 期の変化で压力が非常に大きくなったり小さくなったりす ることがわかる。したがって水位 $20 \%$ の場合で動摆中心 が水面より下にくると $T / T_{n}=1.0$ 付近では常に大きな在 力が発生するものと考えなければならないであろう。

3.3 タンクの側壁における压力分布

\section{3 .1 水位 $90 \%$}

3.2 の水位変化, 3.3 のタンク位置による圧力变化の実 験はすべて圧力測定位置が静水面付近であった。ここでタ ンクの位置の変化によって側壁面上での圧力分布がぞのよ うになるか考光てみる。図 6 は水位 $90 \%$ の場合の圧力 分布図である。縦軸はタンク高さ $1,000 \mathrm{~mm}$ を $100 \%$ と して压力測定したタンクの側壁面上の高さ方向の位置を\% 表示している。横軸は生力を表している。図中の 1.0 , $1.5 \cdots \cdots$ 等の数字は動振周期を表して抒り $T / T_{n}$ の值であ る。図中の○○ $\triangle$ 等の記号は発生した压力が衝撃的な圧力 であったことを表わす。また壁の位置 $100 \%$ での压力は天 并部（壁から $5 \mathrm{~cm}$ 離れた位置）において発生したもので ある。

図 6 ではタンク位矗が 3 通りの場合を示している。上図 はタンクの位置が $z_{3}$ (タンク中心が動摇中心より $80 \mathrm{~cm}$ 上にある）の場合である。中央の図はタンク中心が動摇中 心より $35 \mathrm{~cm}$ 上にある $z_{2}$ の場合である。下眓はタンク中 
心と動摇中心が一致した $z_{1}$ の場合である。

図 6 の 3つの図を比べると明らかにタンク中心と動摇中心とが近づくほど（ $z_{3} \rightarrow z_{2} \rightarrow z_{1}$ となるに従って）発生 する圧力が小さくなって来ていることがわかる。たとえば $T / T_{n}=1.0$ の時, 壁の高さ $95 \%$ での圧力は $z_{3}$ で は $1.1 ， z_{2}$ で $0.7 ， z_{1}$ で 0.3 となっている。特に $T / T_{n}=1.0$ の時, 圧力が增加し始める壁の高さは $z_{3}$ で 60 70\% の位置， $z_{2}$ で 70 80\% の位置， $z_{1}$ で 80 90\% の位置となって括りタンク中心が動摇中心に近づく 程高い位置へと移っていることがわかる。とれと共に発生する玨力も小さくなり $z_{1}$ の位置での最大值は 0.4 程 度であり，z $z_{3}$ での最小值とほぼ同じ位の圧力となっている。よってタンク中心と動摇中心が一致した場合は $T / T_{n}=1.0$ の共振でもあまり大きな生力は出さない。（前報のようにタンク中心が動摇中心より $38 \mathrm{~cm}$ 上にあ る場合では $T / T_{n}=2.0$ で $0.9, T / T_{n}=3.0$ でも 0.4 程度の圧力を発生した。） $T / T_{n}=1.5,2.0$ でもタンク 中心と動摇中心の距離によって発生する王力は大きな影響を受ける。 $T / T_{n}=1.5$ では圧力の最大值が $0.45\left(z_{3}\right)$, $0.45\left(z_{2}\right) ， 0.25\left(z_{1}\right)$ となっており压力分布の特長としては静水面より上で静水面下の压力と比べて少し大きい 值となっている。T/T $=2.0$ では $z_{3}$ の時のみ壁の高さ $80 \%$ 位から大きな值を出す。しかし $z_{1} ， z_{2}$ の位置で は高い圧力を出すこともなく，壁の分布でもほとえど一定の值をとっており，特に高い压力を示す位置はない。 $T / T_{n}=2.5 ， 3.0$ ではタンクが $z_{3}, z_{2} ， z_{1}$ のどの位置にあ っても壁面上での圧力分布はほとんど一定の值でありあま り問題とならない。

\section{3 .2 水位 $60 \%$}

図 7 に水位が $60 \%$ の場合の $z_{3}, z_{2}, z_{1}$ に拉いての壁の 压力分布を示す。図 7 の座標等は図 6 と同じ表わし方をし ている。

水位 $60 \%$ でも $z_{3}, z_{2}, z_{1}$ の三図を比べるとタンク中心 と動摇中心が近づくほど発生する压力は小さくなるという 傾向は水位 $90 \%$ の時と同じである。ただ衝撃压が発生し て高い压力となるのは $T / T_{n}=1.0$ の時だけであり，しか も $z_{3}$ と $z_{2}$ の場合のみである。その最大值は $1.4\left(z_{3}\right)$, $0.5\left(z_{2}\right)$ となっている。さらに $z_{3}$ と $z_{2}$ を比べるとかな りの違いがあることがわかる。つまり衝撃压によって高い 玏を発生し始める壁の高さは $z_{3}$ で $50 \%$ 位であり， $z_{2}$ で $80 \%$ 位から上の位置である。したがって $z_{3}$ では広範 囲に高い压力が壁にかかることになる。そして $z_{1}$ の位置 になると $T / T_{n}=1.0$ でも大きな圧力を出すこともなく， 壁全体にわたりほぼ一定の压力分布であることがわかる。 これはタンクの位置が $z_{1}$ (動摇中心とタンク中心が一致 した時）で水位 $60 \%$ であるため水面と回転中心との距離 は $10 \mathrm{~cm}$ しかなく水が激しく摇れることがないためであ る。

$T / T_{n}=1.0$ 以外の動摇周期では $T / T_{n}=1.5$, タンク位 置 $z_{3}$ の㭙だけ少し大きな值をとるが他の周期では大きく ても圧力が 0.3 位までである。タンク位置が $z_{2}, z_{1}$ にな ると，いずれの動摇周期でも壁の圧力分布は一定であり， その值は小さい。

\section{3 .3 水位 $30 \%$}

図 8 には水位 $30 \%$ の場合の壁に招ける圧力分布図を示 す。図の表わし方は水位 $90 \%$ の場合と同じである。 水位 $30 \%$ でも高い压力が出るのはタンク位置が $z_{3}$ で
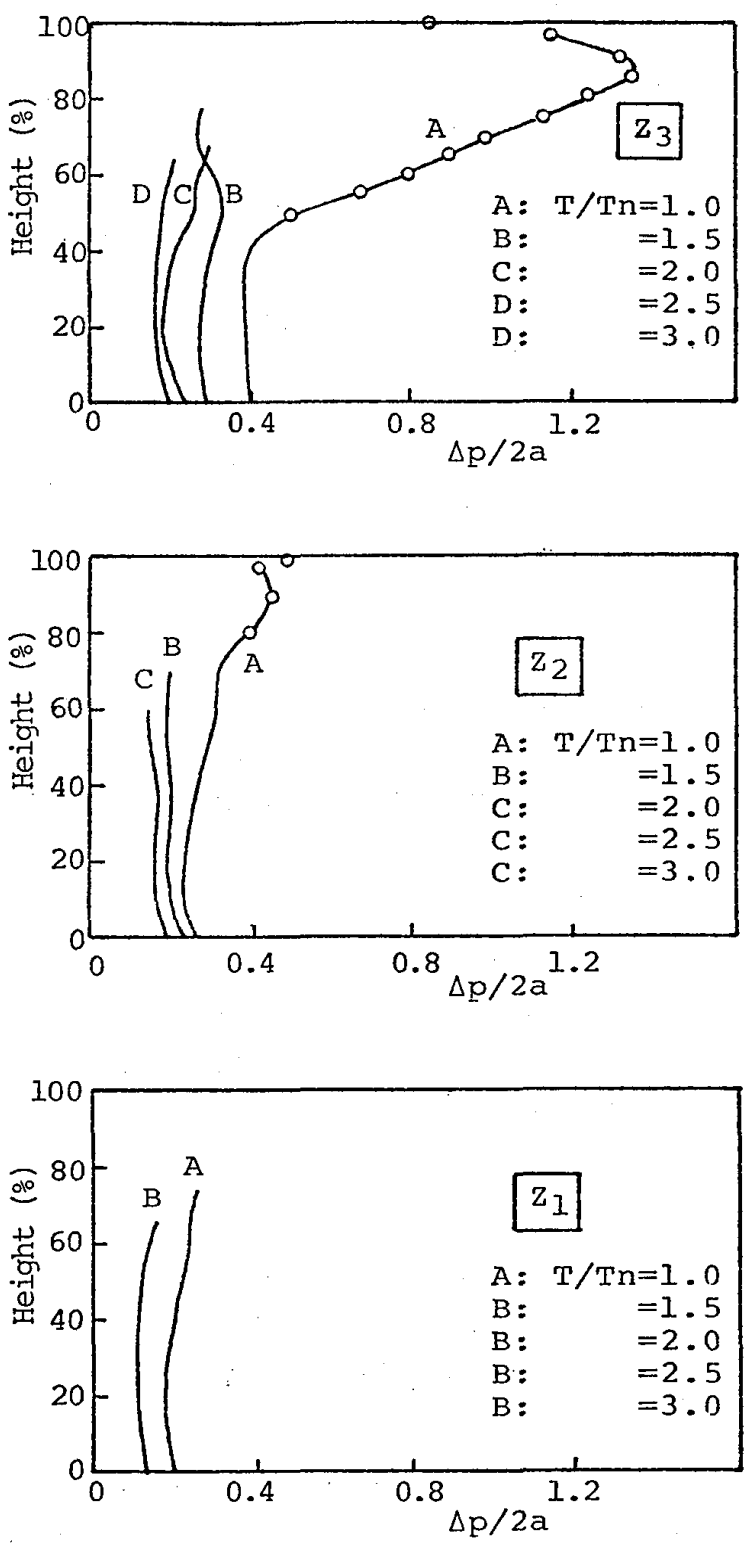

図 7 水位 $60 \%$ 時の壁における圧力分布 

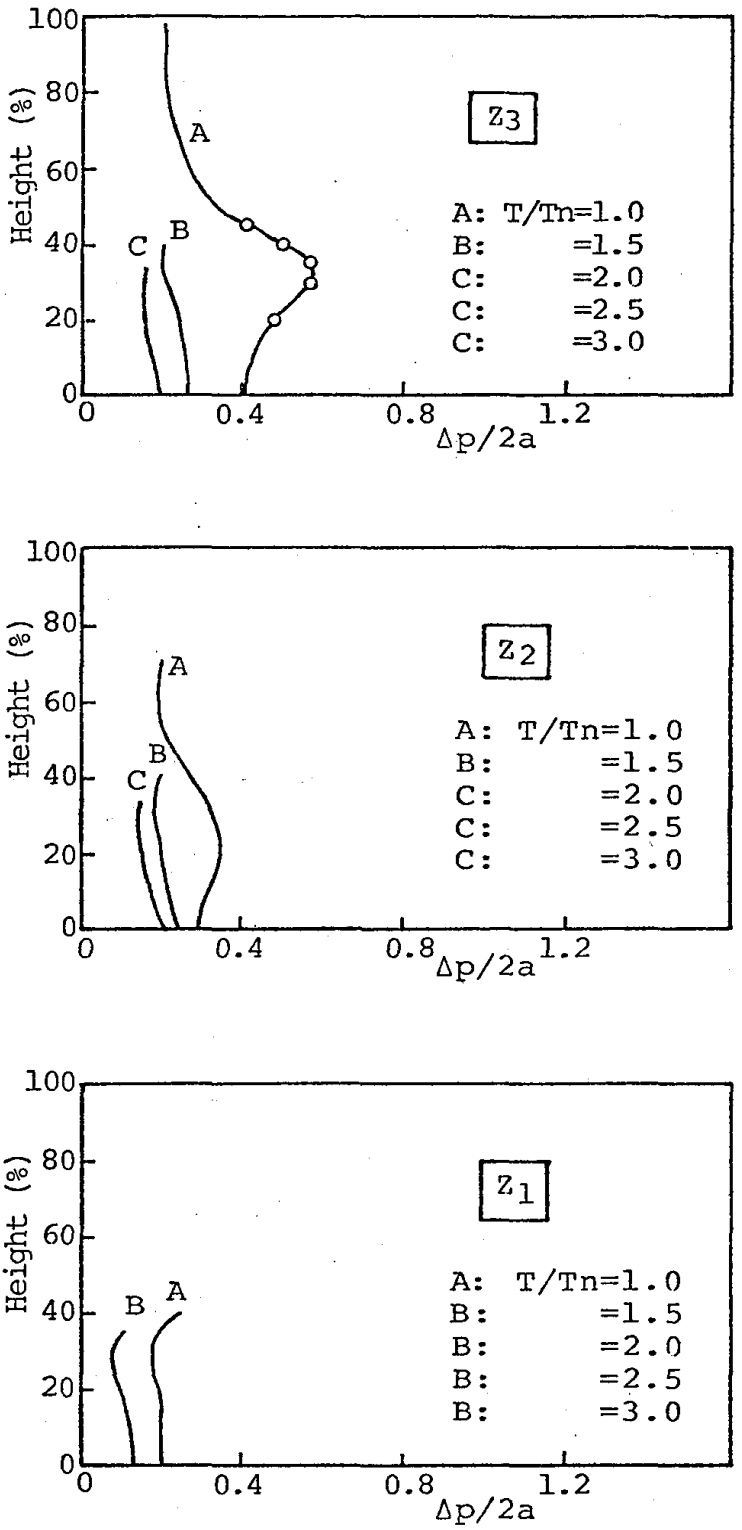

図 8 水位 $30 \%$ 時の壁に打忊圧力分布

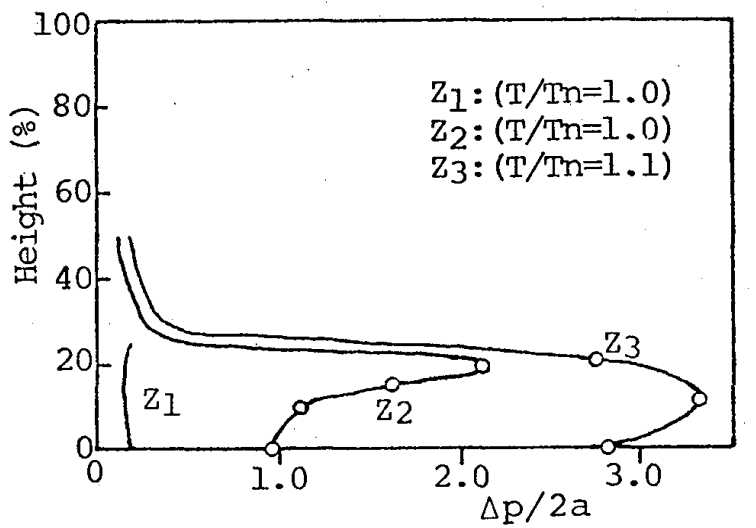

図 9 水位 $20 \%$ 時の壁に括ける圧力分布

$T / T_{n}=1.0$ の時である。この時の圧力分布で特に高い压 力を示すのは水面付近であり，その值は約 0.55 である。 タンク位置が $z_{2}$ で $T / T_{n}=1.0$ の時も王力が最大值とな るのはやはり水面付近であるが值は約 0.35 と小さい。タ ソク位置が $z_{1}$ では水面が動摆中心よりも下方に $20 \mathrm{~cm}$ の 位置にあるため，水の動きは非常に少なく $T / T_{n}=1.0$ で も最大值を示す壁の高さ $40 \%$ の位置で 0.25 と非常に小 さい値であった。

$T / T_{n}=1.0$ 以外の動摇周期ではどの周期でも， 叉タン クが $z_{1}, z_{2}, z_{3}$ のどの位置にあっても压力の高い部分と低 い部分の压力の差は 0.1 以内でありほぼ一定の压力分布と なっていた。

3.3 .4 水位 $20 \%$

図 9 は水位 $20 \%$ の㭙の壁における压力分布である。縦 軸は前述の他の水位と同じく壁の高さを\%表示している。 横軸は他の水位の時と同様に動圧 $\Delta P$ をタンク幅で除した 数値としている。水位 $20 \%$ では $T / T_{n}=1.0$ の付近のみ 非常に高い压力を発生する。したがって特に高い圧力を発 生する動摇周期を選えで $z_{3}$ では $T / T_{n}=1.1 ; z_{2}$ と $z_{1}$ で

は $T / T_{n}=1.0$ の時のみ図に表わした。

前述の他の水位と同様に高い圧力は $z_{3}, z_{2}, z_{1}$ の順に発生する。壁における压力分布をみてみると $z_{3}$ では ンクの底から壁の $25 \%$ 位の間で非常に高い 3.0 前後の圧力を発生している。 $z_{2}$ になる底でも圧力 1.0 とい う大きい值ではあるが，特に高い 2.0 程度の圧力が発生する壁の高さは，水面付近の $20 \%$ 前後とごくせまい範 囲に限られている。

$z_{1}$ になると動摇中心より水面の方が下方になり高い圧力も発生せず，0.2 前後の小さい值でほぼ均一に分布し ていることがわかる。

\section{4 周期一圧力特性}

図 10 から図 13 までは各水位に打ける動摇周期と圧力の関係である。縦軸は $\Delta P / 2 a \cdot$ 值で横軸は $T / T n$

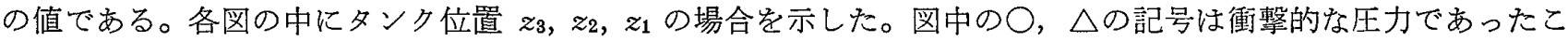
とを走す。

図 10 の水位 $90 \%$ の場合，タンク位置が $z_{3}$ では $T / T_{n}=2.0$ 位から動摇周期が速くなるほど圧力が高くな る。これはこの周期から衝撃圧が発生し始めたためである。 $z_{2}$ になると衝撃圧が発生して任力が高くなり始め るのは $T / T_{n}=1.6$ 位からである。そして $z_{1}$ になると $T / T_{n}=1.2$ 位から少し压力が高くなる程度である。図 


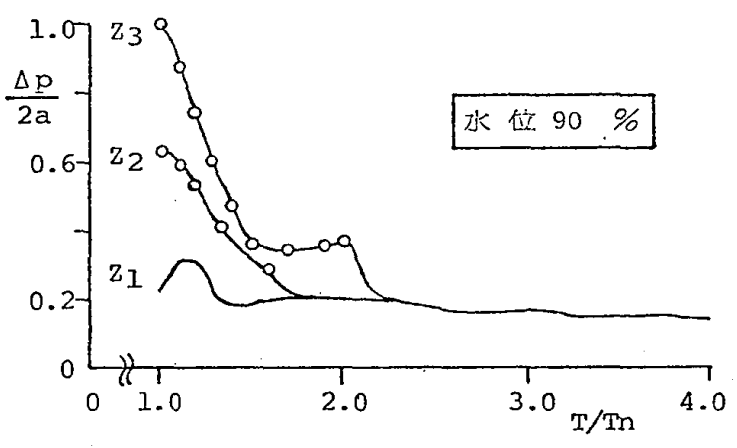

図 10 水位 $90 \%$ 時における任力と周期の関係

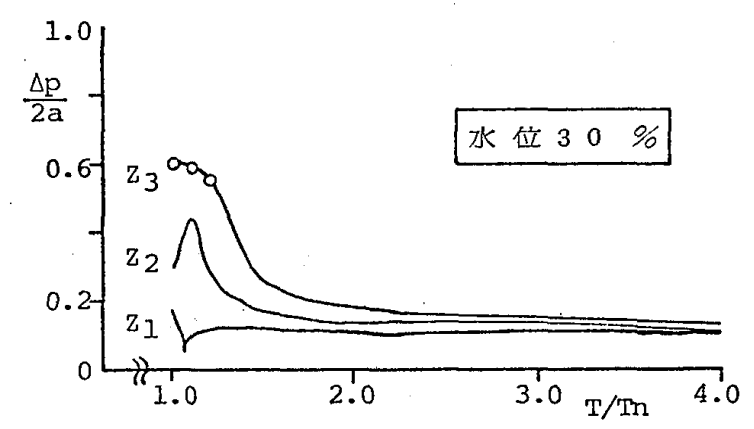

図 12 水位 $30 \%$ 時に打ける圧力と間期の関係

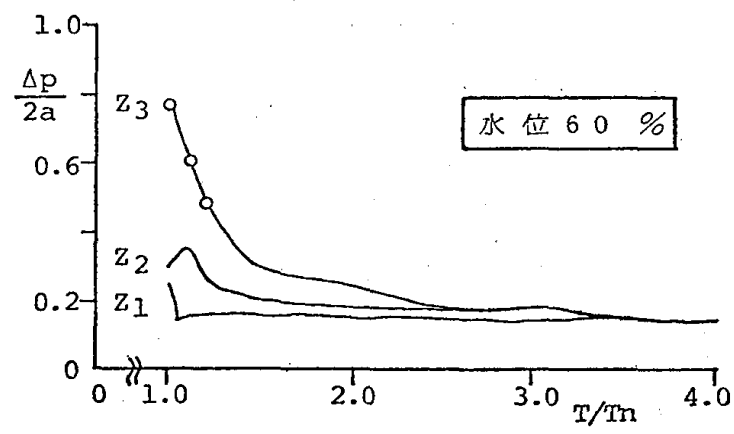

図 11 水位 $60 \%$ 時における圧力と周期の関係

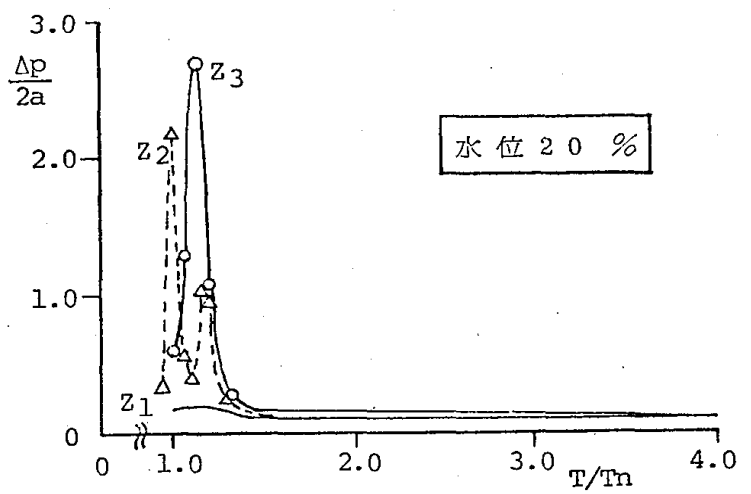

図 13 水位 $20 \%$ 時における圧力と周期の関係

11，図 12 の水位 $60 \% ， 30 \%$ の場合もほぼ同じような傾向にあると言える。

ぞだタンクの位置が $z_{1}$ の時は水位 $30 \%$ に拈いて $T / T_{n}=1.05$ で他のどの周期よりも小さい圧力となって いる。 $T / T_{n}=1.05$ は共振に近い動摇周期であり，他のタンク位置ではほぼ最高圧力に近く $z_{3} て ゙ ~ 0.55 ， z_{2}$ で も 0.4 位となっている。にもかかわらず 0.05 程度の非常に小さい值である。これは水の固有周期と強制動摇周 期が一致したため見かけ上タンク内で水は動かなくなるためである。したがって $T / T_{n}=1.05$ より遅い周期で は傾斜水圧が出ていたが，その傾斜水压も $T / T_{n}=1.05$ では出なくなる。

図 13 の水位 $20 \%$ では $z_{3}$ と $z_{2}$ で非常に高い压力を発生しているが， $z_{3} ， z_{2}$ 共に急激に圧力が上昇し始め るのは $T / T_{n}=1.2$ 位からである。 $T / T_{n}=0.9$ ではどちらも $0.2 \sim 0.4$ 位の值となり高い生力が発生するのは $T / T_{n}=1.0 \sim 1.2$ という非常にせまい範囲であることがわかる。 $z_{1}$ では動摇周期が速くなって $T / T_{n}=1.0$ に 近づいても玏は 0.1〜0.05 位しか增加せず，汪とえど一定の值になっている。

以上，水位を $90 \% ， 60 \% ， 30 \% ， 20 \%$ にした時の压力と周期の関係について述べたが，大体どの水位に㧍い てもタンク位置が $z_{1}$ から $z_{2}, z_{3}$ と上昇するたびに圧力の值も大きくなり，高い压力が発生する周期も広い範囲 になっている。

\section{5 計算值と実験の比較}

図 15, 図 16 には水位 $90 \%$ と $60 \%$ の時の計算值と実験值が示してある。この 計算は O.M. Faltinsen ${ }^{2)}$ の非線型理論を用いた。この理論では液体を非王縮, 非 回転流とした時液体内では次のラプラスの式（1）を満足する。（図 14 参照）

$$
\frac{\partial^{2} \phi}{\partial x^{2}}+\frac{\partial^{2} \phi}{\partial z^{2}}=0
$$

（2）式，(3）式に波の表面の条件を示す。

$$
g \zeta+\frac{\partial \phi}{\partial t}+\frac{1}{2}\left[\left(\frac{\partial \phi}{\partial x}\right)^{2}+\left(\frac{\partial \phi}{\partial z}\right)^{2}\right]=0 \quad z=\zeta(x, t)
$$

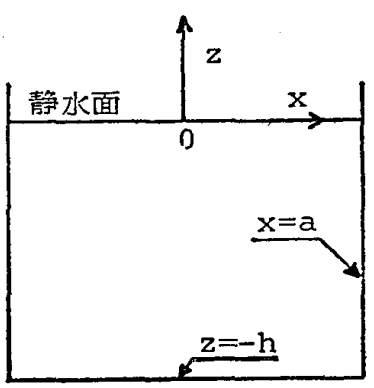

図 14 


$$
\frac{\partial \zeta}{\partial t}-\frac{\partial \phi}{\partial z}+\frac{\partial \phi}{\partial x} \frac{\partial \zeta}{\partial x}=0 \quad z=\zeta(x, t)
$$

タンク壁との境界条件は（4)，(5) 式である。

$$
\begin{array}{ll}
\frac{\partial \phi}{\partial x}=0 & x= \pm a \\
\frac{\partial \phi}{\partial z}=0 & z=-h
\end{array}
$$

（1）式から（5）式をでの条件を満足する $\phi$ 求めるために $\phi を(6)$ 式のようにおいて係数を求め，その $\phi$ を用いると压力 $P$ は (7) 式のようにかける。

$$
\begin{gathered}
\phi=\sum_{n=1}^{\infty} \phi_{n} \varepsilon^{n / 3}, \quad \varepsilon=\frac{A}{2 a} \\
-\frac{P}{\rho}=\frac{\partial \phi_{1}}{\partial t} \theta_{0}^{1 / 3}+\frac{\partial \phi_{2}}{\partial t} \theta_{0}{ }^{2 / 3}+\frac{\partial \phi_{3}}{\partial t} \cdot \theta_{0}+\frac{1}{2}\left(\frac{\partial \phi_{1}}{\partial x}\right)^{2} \theta_{0}{ }^{2 / 3}+\frac{1}{2}\left(\frac{\partial \phi_{1}}{\partial z}\right)^{2} \theta_{0}{ }^{2 / 3} \\
\quad+\frac{\partial \phi_{1}}{\partial x} \frac{\partial \phi_{2}}{\partial x} \theta_{0}+\frac{\partial \phi_{1}}{\partial z} \cdot \frac{\partial \phi_{2}}{\partial z} \theta_{0}+\frac{\partial \phi_{c}}{\partial t}
\end{gathered}
$$

図 15, 図 16 の実線は実験值，点線は計算值を示している。縱軸は圧力，横軸法時間である。動摇周期は $T / T_{n}=1.0$ と 1.5 との二種類とし，動摇角度は $6^{\circ}$ 一定としている。また圧力測定場所は側壁面上で静水面と 底から $40 \%$ の位置拉よび底としている。 $T / T_{n}=1.5$ の場合は水位 $90 \%$ でも $60 \%$ でも大体計算と実験とは よくあっている。特に水面下の場合がよく一致している。 $T / T_{n}=1.0$ では水面下の場合, 大体実験と計算の波 形は似ているが，水面の位置になると水位 $60 \%$ の場合む $90 \%$ の場合むかなり違っている。また波形がよく合 っている場合でも变動圧の值で実験と計算を較べるとかなりの違いがあることがわかる。たとえば水位 $60 \%$ ， $T / T_{n}=1.5$, 測定位置 $40 \%$ のとき, 実験の变動王 0.2 位であるのに対し計算では 0.35 位の值となっている。 また水位 $90 \%$ の実験值は $T / T_{n}=1.0,1.5$ 其に衝揧压を水面で発生している。この衝慗王は水面が上昇し
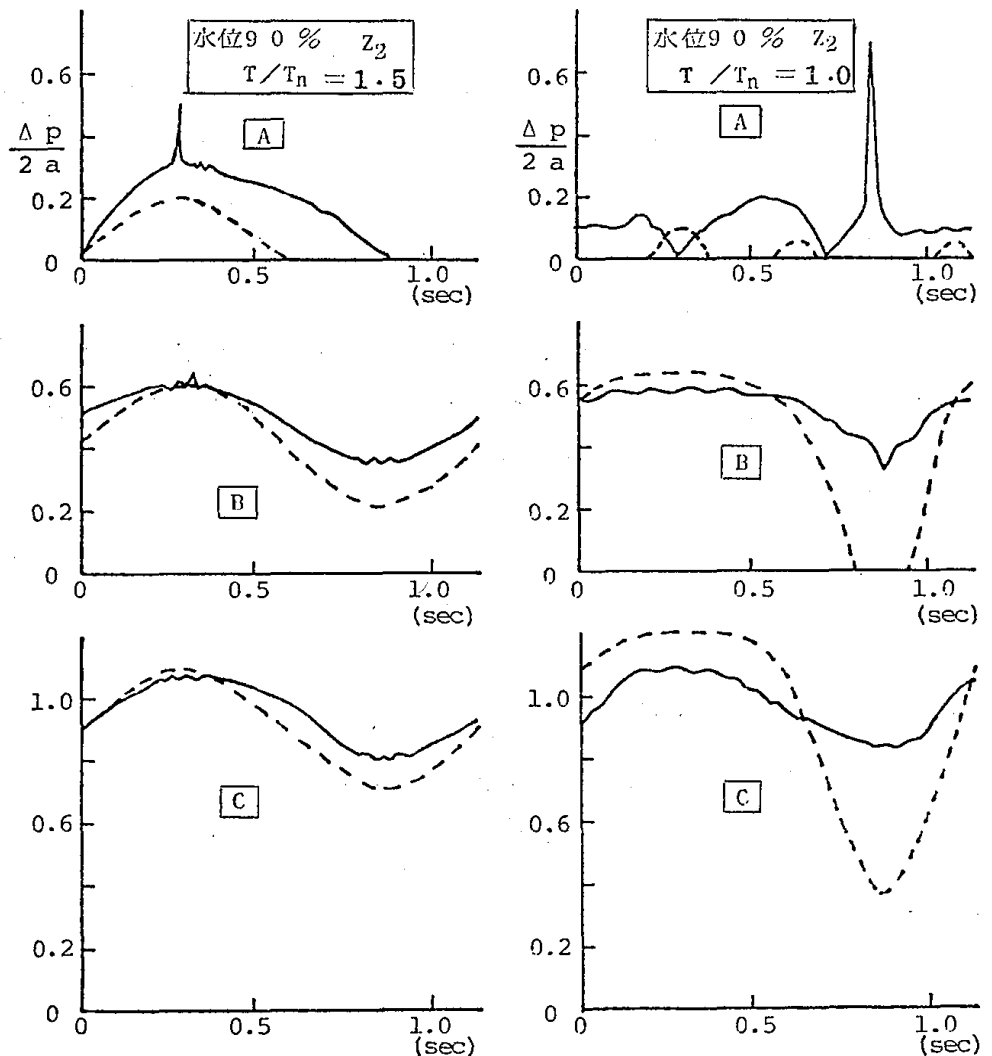

図 15 水位 $90 \%$ に打ける計算と実験の比較 

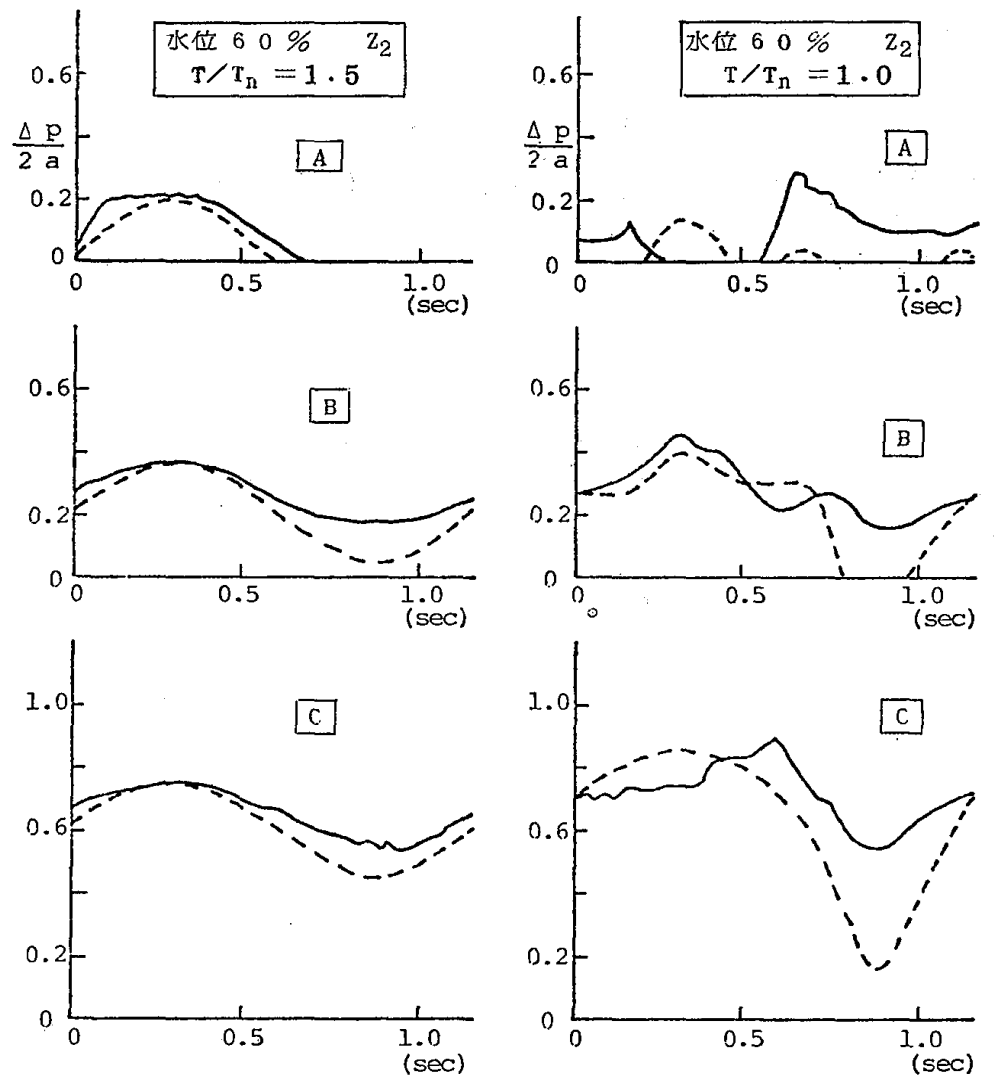

図 16 水位 $60 \%$ における計算と実験の比較

て天井にあたることにより発生するものである。（このことは前にも述べた） Faltinsen の理諭ではオープンタ ンクとして計算しているのでこのような衝撃压は発生しない。したがってこの衝撃圧については他の方法で理諭 的に考党ていかなければならない。

\section{4.むす び}

模型タンクを動摇台に取り付け, 水位, 動摆周期, タンク中心と動摆中心の距離を変えて実験を行なった。そ の結果, 内部の液体が動摇することによってタンク壁に発生する動圧はタンク内の水量, 動摇周期等によって变 化するのはもちろんのととであるが，さらにタンクと動摇中心との距離に大きな影響を受けることが明らかにな った。

それは次のような点である。

（1）側壁に括ける圧力分布では水位をどのように变えてもタンク中心と動摇中心の距離が大になるほど高い 圧力が広い範囲の側壁にわたって発生した。

（2）压力一周期特性の場合もタンク中心と動摇中心の距離が大きくなるほど低い周期から圧力が高くなり始 める。

（3）理諭值と実験值を此べると水面下の王力波形はほぼ一致することが分った。ただ水面付近になると買な ってくる。天井部に発生する衝揧压は Faltinsen の理論では天井を考光ていないので別の理論老考える必要があ る。今後この点について検討を加えていくつもりである。

終りに, 本研究の実験装置等の製作およびデータの整理等について卒業研究の学生 重谷, 中野, 坂東, 山口 の諸君に協力を得たことを付記して扔礼申し上げます。 


\section{参考 文 献}

（1）今枝，木村：動摇する角型タンク内の動的水压, 日本航海学会諭文集, 59 号（昭 53/8）

(2) O.M. Faltinsen: A Nonlinear Theory of Sloshing in Rectangular Tanks, J. of Ship Res. Vol. 18, No. 4, Dec. (1974) 